\title{
Sensory analysis of enzyme- and membrane-treated peach juices
}

Márcia M. Santin ${ }^{1}$, Helen Treichel ${ }^{1}$, Eunice VALduga ${ }^{1}$, Lourdes M.C. Cabral ${ }^{2}$, Marco Di Luccio ${ }^{3 *}$

${ }^{1}$ Programa Pós-grad. Eng. Aliment., Univ. Integr. Alto Urug. Missões, Campus Erechim, Av. Sete de Setembro, 1621, Erechim RS, 99700-000, Brazil

2 Embrapa Agroind. Aliment., Av. das Américas 29501, Guaratiba, 23020-470, Rio J., RJ, Brazil

${ }^{3}$ Dep. Eng. Quím.Eng. Aliment., Univ. Fed. St. Catarina, Caixa Post. 476, Florianópolis, 88040-900, SC, Brazil, mdiluccio@gmail.com

${ }^{*}$ Correspondence and reprints

Received 11 June 2011 Accepted 4 October 2011

Fruits, 2012, vol. 67, p. 451-461 (C) 2012 Cirad/EDP Sciences All rights reserved DOI: 10.1051/fruits/2012041 Www.fruits-journal.org

RESUMEN ESPAÑoL, p. 461

\section{Sensory analysis of enzyme- and membrane-treated peach juices.}

Abstract - Introduction. The aim of this work was to develop a list of suitable sensory attributes and to perform sensory quality assessment of an unprocessed peach juice and a peach juice clarified by enzymatic treatment followed by membrane processes, using the attributes chosen by the trained panel. Materials and methods. A panel of assessors was selected and trained following the quantitative descriptive analysis methodology. A descriptive terminology with eight descriptors was successfully developed. Results and discussion. The sensory analysis showed that the juices were effectively clarified. Although the clarification by microfiltration in a bench-scale unit did not change juice taste attributes, the characteristic color and aroma of peach juice were also removed. The scale-up of the membrane clarification process affected all the sensory characteristics of the clarified juice, even taste. The unpleasant cooked fruit taste and aroma could be reduced by juice clarification by enzymatic and membrane processes. The kind of membrane, membrane geometry and transmembrane pressure used in the membrane clarification did not significantly affect the juice sensory characteristics.

Brazil / Prunus persica / fruit juices / quality / clarifying / microfiltration / ultrafiltration / flavor / color

\section{Analyse sensorielle du jus de pêche clarifié par des traitements enzymatiques et membranaires.}

Introduction. L'objectif de ce travail a été de définir une liste d'attributs sensoriels pour comparer la qualité sensorielle du jus de pêche non transformé et du jus de pêche clarifié par traitement enzymatique suivi d'un procédé membranaire, en utilisant les attributs choisis par un panel qualifié. Matériel et méthodes. Un panel d'évaluateurs a été sélectionné et entraîné en utilisant la méthode de l'analyse descriptive quantitative. Une terminologie descriptive de huit descripteurs a été développée avec succès. Résultats et discussion. L'analyse sensorielle a montré que le jus a effectivement été clarifié. Bien que la clarification par microfiltration à l'échelle du laboratoire n'ait pas modifié les attributs du goût du jus, la couleur et l'arôme caractéristiques du jus de pêche ont été perdus. À l'échelle expérimentale, le processus de clarification membranaire a affecté toutes les caractéristiques sensorielles du jus clarifié, y compris son goût. Le goût et l'arôme désagréables des fruits cuits pourraient être atténués en clarifiant le jus par couplage de procédés enzymatiques et membranaires. Le type de la membrane, la géométrie membranaire ainsi que la pression transmembranaire utilisés pendant la clarification n'ont pas affecté sensiblement les caractéristiques sensorielles du jus.

Brésil / Prunus persica / jus de fruits / qualité / clarification / microfiltration / ultrafiltration / flaveur / couleur 


\section{Introduction}

The demand for healthy and nutritious food and beverage products has been growing and creates new opportunities for fruit juice markets, due to the increase in the consumption of juices and fruit-based drinks such as nectars, cocktails, and yogurt-based drinks containing prebiotics [1-3].

According to the Food and Agriculture Organization, world production of peaches and nectarines in 2009 was approximately 19.0 Mt. The main producers are China, Italy, EUA and Spain ${ }^{1}$.

Depending on the kind of beverage product, clarification of fruit juices may be needed. Compared with conventional juice clarification processes, based on the use of fining agents (gelatine, bentonite, silica sol, diatomaceous earth, etc.), membrane processes are advantageous since they are lowcost, athermal separation techniques, which involve no phase change or chemical agents. These features are becoming very important factors in the production of new fruit juices with natural fresh taste and additive-free [4].

Pretreatment with pectinolytic and cellulolytic enzymes is frequently needed, however, since fruit juices contain colloids (pectin, cellulose, hemicellulose, lignin and starch) that may lead to fouling problems during the filtration process. The enzymatic treatment can increase the permeate flux in the microfiltration, ultrafiltration and reverse osmosis of fruit juices [5-7].

One important step in fruit juice formulations is their sensory characterization. Even mild processing steps like enzymatic treatment and membrane filtration can impair the sensorial characteristics of the fruit juice. So far, little is known about sensory characterization of peach juices, including juices that were clarified by enzymatic and membrane processes. There is a lack in the literature, especially on the development of a sensory panel and a list of sen-

\footnotetext{
${ }^{1} \mathrm{FAO}$ (2012). Food and Agriculture Organization, FAOSTAT Database. Available: http://faostat. fao.org. Accessed in January 2012.
}

sory descriptors suitable for descriptive analysis of this type of juice. The use of qualified panels applying specific evaluation methods for sensory quality control increases the reliability of the results [8]. Crucial aspects of conventional profiling are the selection of appropriate terms and the recruitment and training of appropriate judges. The terms can be selected from previous existing lists or specifically generated by a panel of assessors [9]. Descriptors exist for orange and mandarin juices [10, 11], but no report on sensory analysis of peach juice has been found elsewhere, nor a sensory evaluation of peach juices clarified by enzymatic treatment followed by microfiltration or ultrafiltration.

In this context, the aim of our work was to select and analyze the performance of a group of assessors, to develop a list of suitable sensory attributes and to perform sensory quality assessment of an unprocessed peach juice and a peach juice clarified by enzymatic treatment and membrane processes, using the attributes chosen by the trained panel.

\section{Materials and methods}

\subsection{Preparation of the peach juices}

Two varieties of a commercial peach (Prunus persica L.) pulp (yellow and white) from the same batch, obtained from a local producer, were used in all experiments. Pulps were diluted with a suitable amount of water to prepare the peach juice. The processed peach juice was obtained by a treatment with a commercial enzyme, followed by microfiltration or ultrafiltration. The enzymatic treatment was carried out following the procedure previously optimized by our research group [12]. A suitable amount of peach pulp was treated with $240 \mathrm{mg} \cdot \mathrm{kg}^{-1}$ of a commercial mixture of pectinases (Pectinex AFPL-3, Novozymes, Curitiba, Brazil), at $25^{\circ} \mathrm{C}$ for $60 \mathrm{~min}$. The hydrolyzed juice was then clarified by microfiltration or ultrafiltration using different membrane systems (table I). 
Table I.

Characteristics of the membrane systems used for peach juice clarification.

\begin{tabular}{|c|c|c|c|}
\hline Membrane system & Membrane & $\begin{array}{c}\text { Membrane area } \\
\left(\mathrm{m}^{2}\right)\end{array}$ & $\begin{array}{l}\text { Transmembrane pressure } \\
\qquad(\mathrm{kPa})\end{array}$ \\
\hline Bench-scale cross-flow module & Sartorius $0.2 \mu \mathrm{m}$ cellulose acetate & 0.0049 & 100 \\
\hline $\begin{array}{l}\text { Protosep IV, } \\
\text { Koch Membrane Systems }\end{array}$ & $\begin{array}{l}\text { Koch, } 0.3 \mu \mathrm{m} \\
\text { polyethersulfone }\end{array}$ & 0.05 & 150 \\
\hline $\begin{array}{l}\text { Protosep IV, } \\
\text { Koch Membrane Systems }\end{array}$ & Koch $0.1 \mu \mathrm{m}$ ceramic & 0.0055 & 180 \\
\hline M20, DDS & GRM01PP, DDS, $0.1 \mu \mathrm{m}$ & 0.61 & 400 \\
\hline M20, DDS & $\begin{array}{c}\text { GR40PP, DDS } \\
100 \mathrm{kDa} \text { molecular weight cut-off }\end{array}$ & 0.267 & 700 \\
\hline
\end{tabular}

\subsection{Sensory analysis}

The sensory analysis was carried out using the Quantitative Descriptive Analysis method $^{\circledR}$ (QDA), which is well described elsewhere [13]. QDA training takes less time than other methods and has been applied in many studies [14].

\subsection{Selection of assessors}

A group of 39 assessors was selected for their habit of consuming fruit juices. The age of assessors varied from 19 to 50 years old. The selection of the best candidates was carried out by discriminative tests (triangle test for difference testing): basic tastes (sweet, salty, bitter, sour), intensity of taste, mixture of basic tastes, and odor and aroma recognition. The candidates that scored at least $80 \%$ of the correct answers were selected. A standard product was formulated with a commercial raw peach pulp. Triads of the standard product studied were performed with variations in the concentration of sugar, dilution of the juice, aroma, flavor and turbidity. The assessors that scored more than $60 \%$ of the correct answers were selected.

Tests were conducted in a standard room equipped with a table for joint sessions and nine individual tasting booths. Samples were thawed in water baths on the same day as testing and served at room temperature (about $20^{\circ} \mathrm{C}$ ) in transparent glasses labeled with random 2-digit codes. Water was provided to rinse the mouth between evaluations.

\subsection{Definition of descriptors}

The definition of descriptors was carried out by 19 selected assessors that discussed the similarities and differences among the samples, according to their characteristics, namely visual (color, turbidity), odor (peach-like aroma and cooked peach aroma) and taste (sweetness, peach-like taste, cooked fruit taste and acidity). The sensory descriptors were discussed by the assessors and selected by consensus from all the terms generated by the taste panelists.

\subsection{Training of assessors}

After the definition of the descriptors and characteristic profile of the peach juice, the assessors were submitted to training, when reference standards were used as examples of the defined quality descriptors.

The training of the sensory panel to evaluate the descriptors followed structured line scales $(9 \mathrm{~cm})$ anchored at the ends with terms related to the descriptors. Diluted 
Figure 1.

Percent of assessors selected in the discriminative tests for characterizing the taste and aroma of peach juices clarified with different processes.

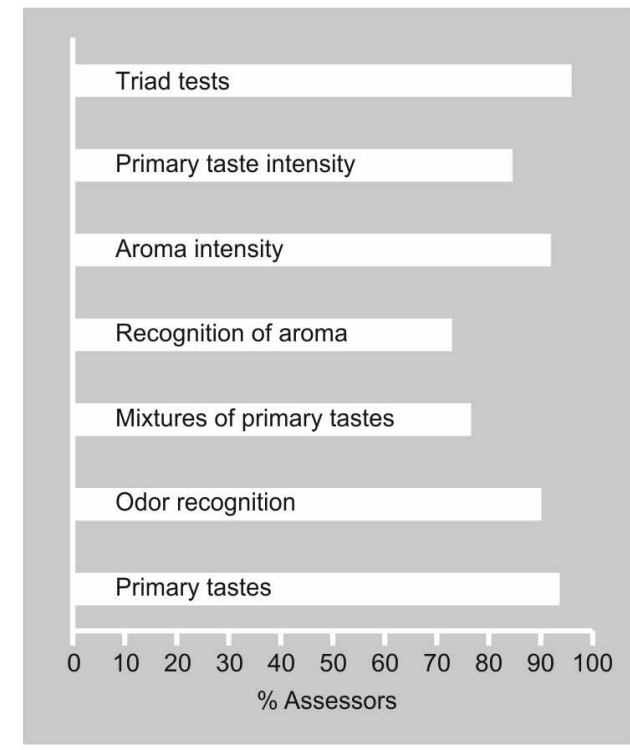

juice $(1: 10 \mathrm{v} / \mathrm{v})$ was used as a weak standard and the strong standard was prepared with the undiluted juice, with added sugar and citric acid and cooked, as standards of strong sweet taste, strong acid taste and strong cooked taste.

The performance of the assessors was checked with the following tests. Three representative samples of each descriptor were presented to the panel, and each assessor evaluated three repetitions of the three samples. The individual results of the assessors and of the descriptors (color, turbidity, aroma and taste) were statistically analyzed by analysis of variance (ANOVA) and Tukey's test at the 5\% level of significance. Analysis of variance of three factors (sample, repetition and panel consensus) was performed for each assessor with respect to each attribute, and the assessors were selected according to values of significant $\mathrm{F}_{\text {sample }}(p<0.30$, or $p<30 \%)$ and non-significant $\mathrm{F}_{\text {repetition }}(p>0.05$ or $p>5 \%)$. The agreement of the sensory panel was also verified by the conditions: 1) the assessors' individual means should be similar to each other; 2) these individual means should also be close to the panel's means for all the evaluated attributes; 3 ) the interaction between the sample mean $\times$ assessor mean should not be significant $(\phi>0.05)$. The assessors were then selected based on their ability to discriminate among different samples, repeatability and agreement with the group [15].

\subsection{Sensory profile of the juices}

The juices that were clarified by enzymatic treatment and membrane processes (microfiltration or ultrafiltration) were evaluated by the trained panel of assessors. The attributes that were assessed were color, turbidity, taste and aroma, based on the descriptors defined by the panel of assessors. The intensities of the sensory attributes were analyzed by structured scales $(9 \mathrm{~cm})$ anchored at the ends with terms related to the descriptors. The results were statistically analyzed by Tukey's test at the 5\% level of significance.

\section{Results and discussion}

\subsection{Selection of assessors}

Of the total of 39 individuals that participated in the preliminary selection, $41 \%$ were female and $59 \%$ male, with a predominant age from 20 to 30 years. The preliminary selection involved an interview with the candidates with questions about their health status, allergies, smoking, dietary habits and motivation to take part in the panel. Thirtytwo candidates were pre-selected based on their consumption habits and medical conditions. Nineteen individuals were selected for their ability to recognize primary tastes, odor, mixtures of primary tastes, aroma, aroma intensity and primary taste intensity (figure 1).

\subsection{Definition of descriptors}

After definitions of the descriptors of peach juices, the assessors discussed the descriptors in a round table to eliminate redundancies, synonyms or terms that were seldom cited. Ten descriptive terms were defined by the assessors. The definition of descriptors and the intensity references that anchored the extremes of the scales of evaluation were listed (table II). 


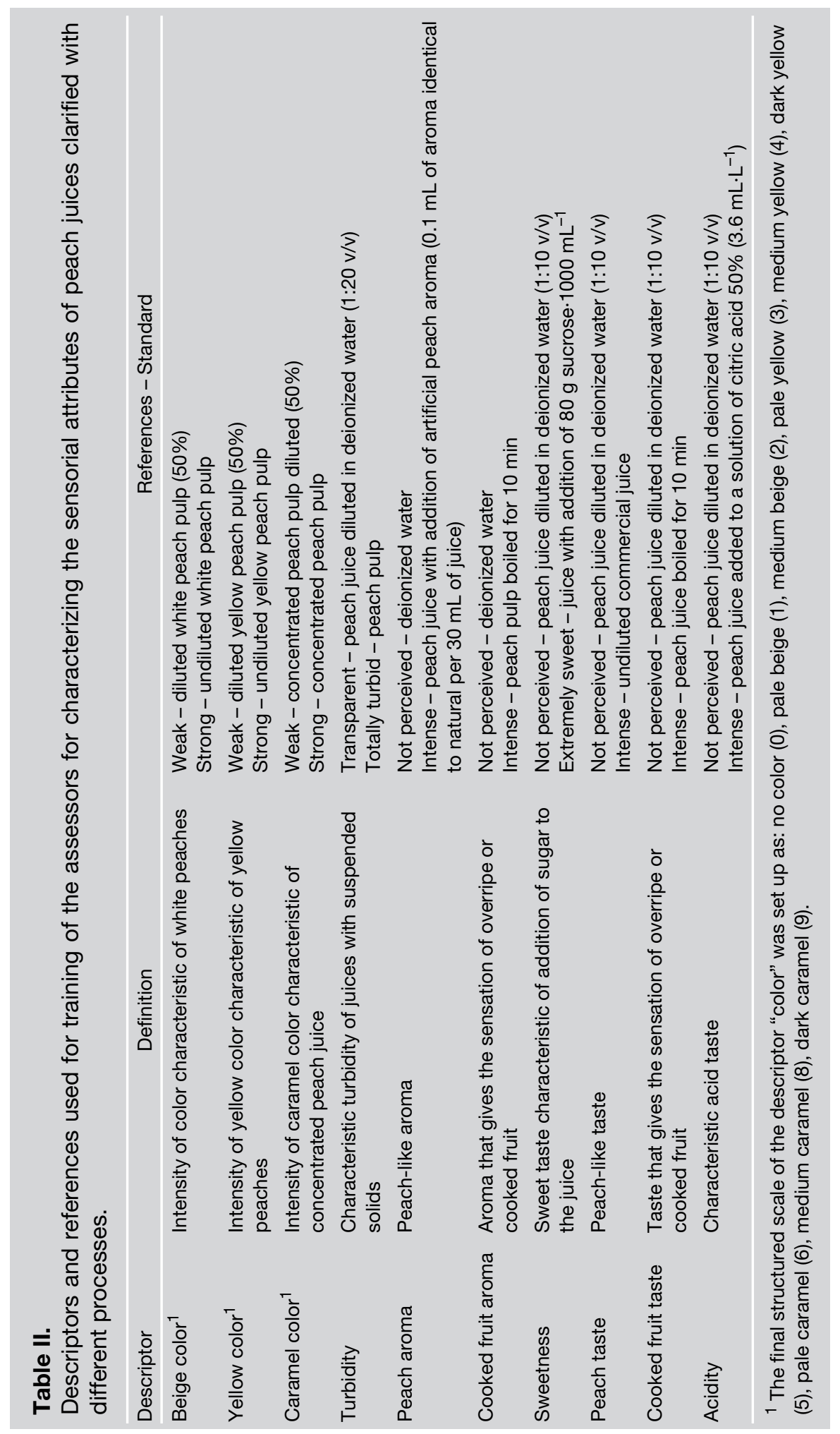


The sensory descriptors defined in the present work follow the same trend as those obtained in orange juices. A trained panel described by Jesus et al. defined, for orange juice concentrated by reverse osmosis, sensory descriptors such as characteristic aroma and taste, orange peel aroma and taste, acid taste, cooked taste and suspended particles [16]. Similarly, Carbonell et al. defined descriptors of mandarin juice, such as fruit aroma and taste, cooked taste, acidity, and sweetness, among others [9].

\subsection{Assessor training}

Eight assessors were selected for their discriminative ability $\left(\phi \mathrm{F}_{\text {sample }}<0.30\right)$ and reproducibility $\left(\phi \mathrm{F}_{\text {repetition }}<0.5\right)$ (table III) and consensus with the panel of assessors by comparison of individual means for each descriptor with the means of the whole panel.

\subsection{Sensory profile of the juices}

The averages and standard deviations for each descriptor of peach juices treated in a bench-scale microfiltration system were listed (table $I V)$. The sensory turbidity of the clarified juices significantly differs from unprocessed juice samples, confirming the effective clarification of the juice and the physical chemical analysis (results not shown). The same behavior could be observed in the color, that changes from dark caramel (sample 2) to pale beige (sample 3), showing that most of the color is retained with the suspended solids of the juice. The analyzed taste descriptors did not significantly differ at a $p$-level $<0.05$. Only the acid taste of sample 4 was more intense when compared with the other samples, possibly due to sugar retention in the suspended solids or incorporation of carbon dioxide during microfiltration. In fact, the concentration of total reducing sugar of some samples decreased after membrane processing (results not shown). This behavior has also been observed by other studies of microfiltration of natural juices [17].

The cooked fruit aroma of sample 1 (white peach juice) was significantly different from the sample of yellow peach pulp, since the extraction of pulp of yellow peaches was carried out under high temperatures (80$90{ }^{\circ} \mathrm{C}$ ). It is interesting to note that the microfiltration treatment decreases this aroma. This effect could happen due to volatilization of aroma compounds during processing steps or even due to retention in the suspended solids. The taste, however, is not significantly changed after clarification.

The averages and standard deviations for each descriptor of peach juices treated in the pilot-scale microfiltration system are listed (table V). The sensory quality of permeates obtained in the pilot systems was very similar to the clarified juices obtained in the bench-scale unit (table IV). Again, sensory color was significantly changed due to microfiltration, due to color retention with the suspended solids.

The peach aroma, differently from the bench-scale results, did not change after juice clarification, possibly due to the shorter time of processing when compared with the bench-scale microfiltration system. The results for the descriptors taste of cooked fruit, sweetness, acidity, peach taste and cooked fruit aroma significantly changed when the juice was clarified in pilot-scale microfiltration and ultrafiltration systems. The decrease in the cooked aroma is a positive result, since the final quality of the product is increased. The acidity of the fraction of the juice that was permeated through the membranes was intensified, as in the bench-scale system, probably due to the aeration of the samples during processing or removal of sugars with the suspended solids.

The peach taste of the clarified peach juice (permeate fractions) was lower than the peach taste of the unprocessed juice, which is a negative result. This behavior could be due to retention of taste with suspended solids, or the intensified acidity might be masking other flavors.

The sensory characteristics of permeate fractions of the different membrane systems are equal, proving that the conditions of clarification, like the type of membrane, module geometry and pore size (between $0.3 \mu \mathrm{m}$ and $100 \mathrm{kDa}$ of molecular weight cut-off), do not affect the sensory quality of the clarified juice much. 


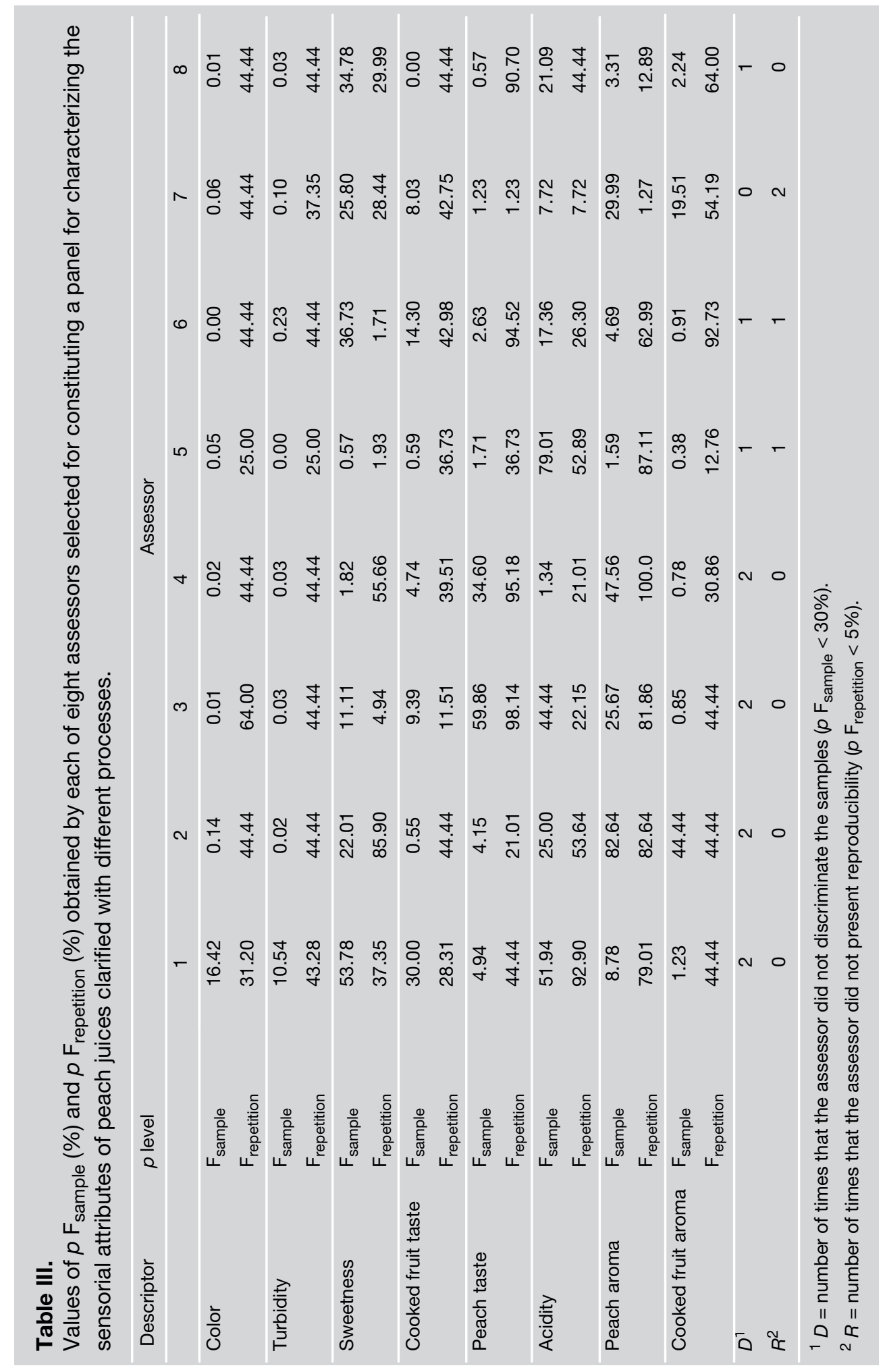


M.M. Santin et al.

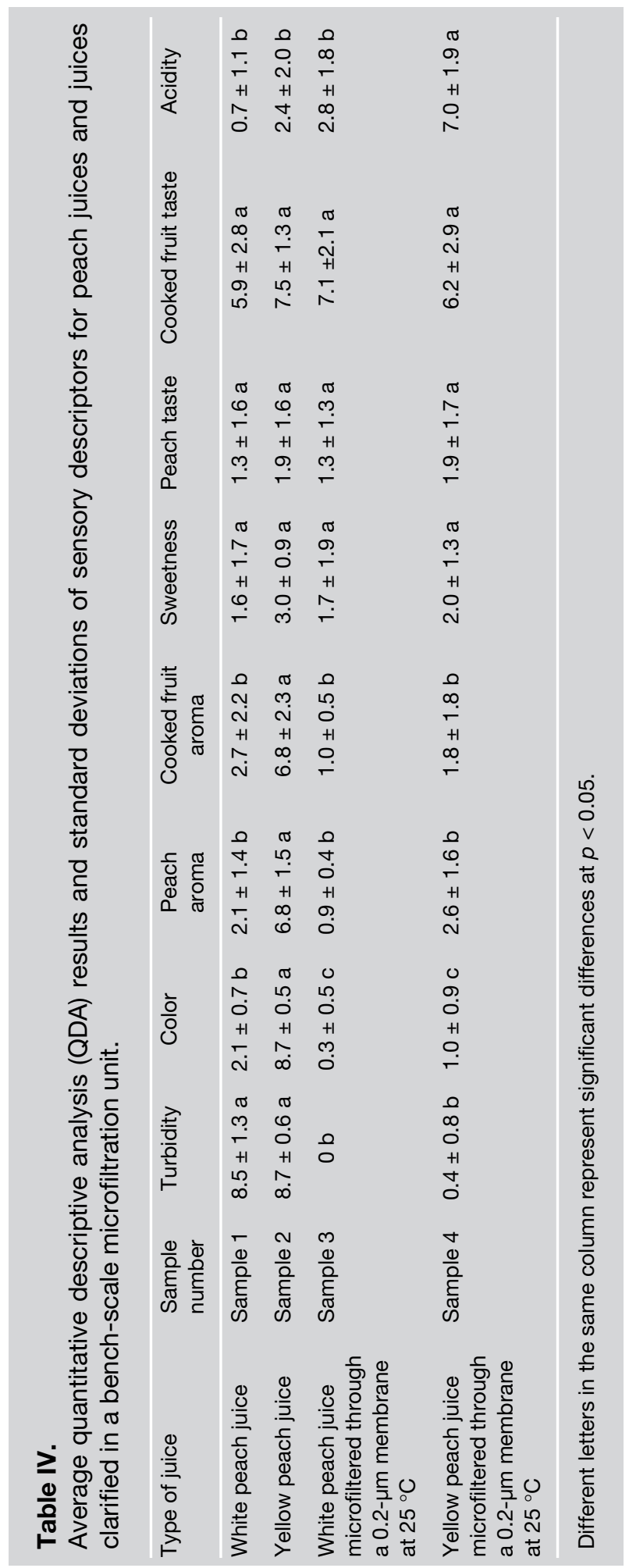




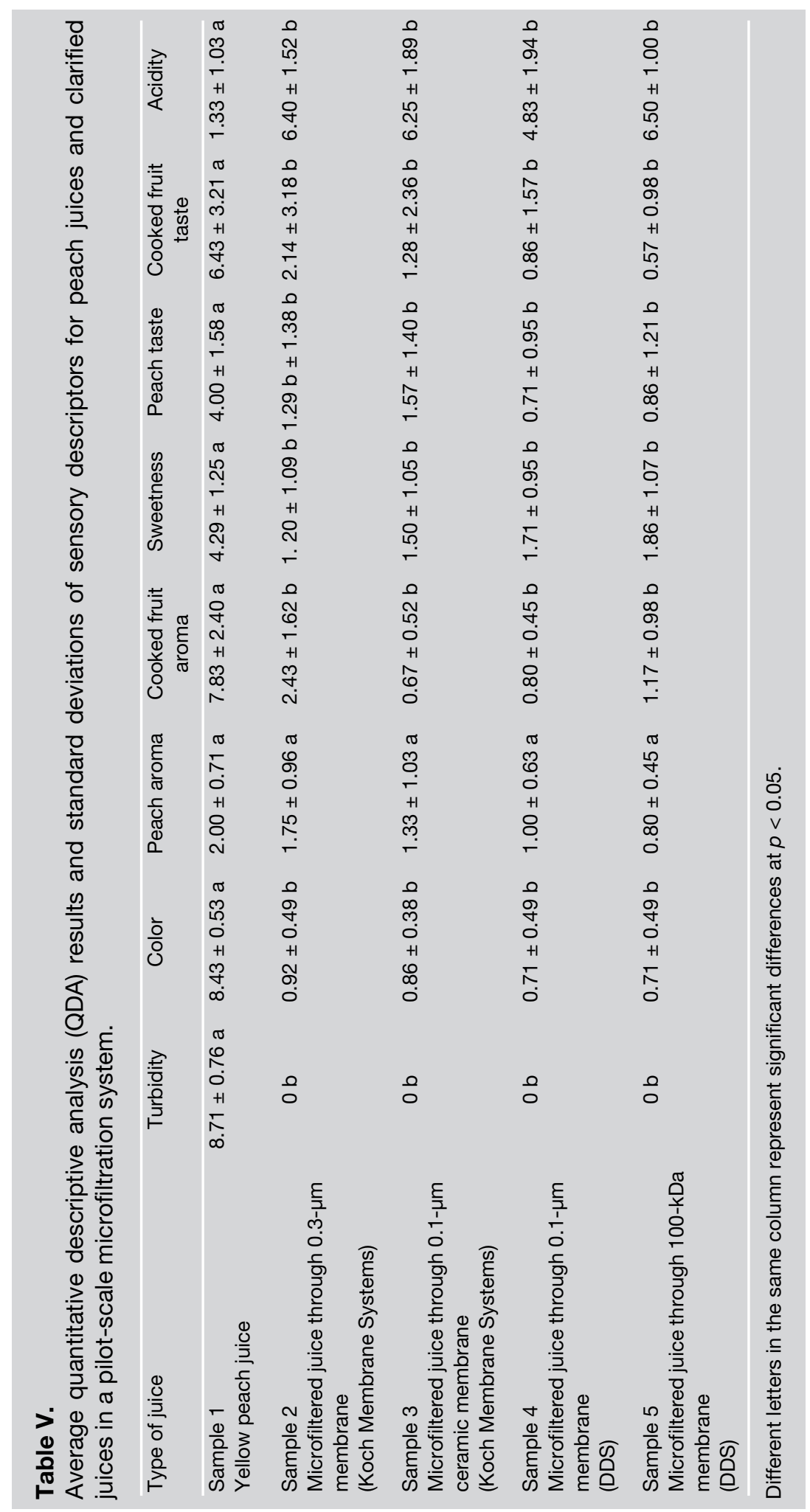




\section{Conclusions}

In this work we presented insights into the sensory profile and quality of enzyme- and membrane-treated peach juices. The trained panel of assessors developed a descriptive terminology with eight descriptors defining the similarities and differences among the samples related to visual characteristics (color, turbidity), aroma (peach aroma and cooked fruit aroma) and taste (sweetness, acidity, peach taste and cooked fruit taste). The sensory analysis showed that the juices were effectively clarified. Although the clarification by microfiltration in a bench-scale unit did not change juice taste attributes, the characteristic color and aroma of peach juice were removed, yielding pale-colored juices with a less pronounced peach taste. The scale-up of the membrane clarification process affected all the sensory characteristics of the clarified juice, even taste. The unpleasant cooked fruit taste and aroma could be reduced by juice clarification by enzymatic and membrane processes. The kind of membrane, membrane geometry and transmembrane pressure used in the membrane clarification did not significantly affect the juice sensory characteristics.

\section{References}

[1] Matta V.M., Moretti R.H., Cabral L.M.C., Microfiltration and reverse osmosis for clarification and concentration of acerola juice, J. Food Eng. 61 (2004) 477-482.

[2] Gonzalez N.J., Adhikari K., Sancho-Madriz M.F., Sensory characteristics of peach-flavored yogurt drinks containing prebiotics and synbiotics, LWT Food Sci. Technol. 44 (2011) 158-163.

[3] Sabbe S., Verbeke W., Van Damme P., Analysing the market environment for acai (Euterpe oleracea Mart.) juices in Europe, Fruits 64 (2009) 273-284.

[4] Cassano A., Conidi C., Drioli E., Clarification and concentration of pomegranate juice (Punica granatum L.), J. Food Eng. 107 (2011) 366-373.

[5] Rai P., Majumdar G.C., DasGupta S., De S., Optimizing pectinase usage in pretreatment of mosambi juice for clarification by response surface methodology, J. Food Eng. 64 (2004) 397-403.
[6] Liew Abdullah A.G., Sulaiman N.M., Aroua M.K., Megat Mohd Noor M.J., Response surface optimization of conditions for clarification of carambola fruit juice using a commercial enzyme, J. Food Eng. 81 (2007) 65-71.

[7] Ganga A., Piñaga F., Querol A, Vallés S., Ramón D., Cell-wall degrading enzymes in the release of grape aroma precursors, Food Sci. Technol. Int. 7 (2001) 83-87.

[8] Etaio I., Albisu M., Ojeda M., Gil P.F., Salmerón J., Pérez Elortondo F.J., Sensory quality control for food certification: A case study on wine. Panel training and qualification, method validation and monitoring, Food Cont. 21 (2010) 542-548.

[9] Carbonell L., Izquierdo L, Carbonell I., Sensory analysis of Spanish mandarin juices. Selection of attributes and panel performance, Food Qual. Pref. 18 (2007) 329341.

[10] Rega B., Fournier N., Nicklaus S., Guichard E., Role of pulp in flavor release and sensory perception in orange juice, J. Agric. Food Chem. 52 (2004) 4204-4212.

[11] Spoto M.H.F., Domarco R.E., Walder J.M.M., Scarminio I.S., Bruns R.E., Sensory evaluation of orange juice concentrate as affected by irradiation and storage, J. Food Process. Preserv. 21 (1997) 179-191.

[12] Santin M.M., Treichel H., Valduga E., Cabral L.M.C., Di Luccio M., Evaluation of enzymatic treatment of peach juice using response surface methodology, J. Sci. Food Agric. 88 (2008) 507-512.

[13] Stone H., Sidel J.L., Oliver S., Woolsey A., Singleton R.C., Sensory evaluation by Quantitative Descriptive Analysis, Food Technol. 28 (1974) 24-33.

[14] Murray J.M., Delahunty C.M., Baxtera I.A., Descriptive sensory analysis: past, present and future, Food Res. Int. 34 (2001) 461-471.

[15] Bannwart G.C.M.C., Bolini H.M.A., Toledo M.C.F., Kohn A.P.C., Cantanhede G.C., Evaluation of Brazilian light ketchups. II: quantitative descriptive and physicochemical analysis, Ciênc. Tecnol. Aliment. 28 (2008) 107-115.

[16] Jesus D.F., Leite M.F., Silva L.F.M., Modesta R.D., Matta V.M., Cabral L.M.C., Orange (Citrus sinensis) juice concentration by reverse osmosis, J. Food Eng. 81 (2007) 287-291.

[17] Silva T.T., Della Modesta R.C., Penha E.M., Matta V.M., Cabral L.M.C., Organic passion fruit juice processed by microfiltration, Pesqui. Agropecu. Bras. 40 (2005) 419-422. 


\section{Análisis sensorial del zumo de melocotón clarificado por tratamientos enzimáticos y de membrana.}

Introducción. El objetivo de este trabajo fue definir una lista de atributos sensoriales para comparar la calidad sensorial del zumo de melocotón no transformado y la del zumo de melocotón clarificado por tratamiento enzimático seguido de un proceso de membrana, empleando los atributos elegidos por un grupo de expertos cualificado. Material y métodos. Se seleccionó y se preparó a un grupo de evaluadores expertos empleando el método del análisis de descripción cuantitativo. Se desarrolló exitosamente una terminología descriptiva de ocho descriptores. Resultados y discusión. El análisis sensorial reveló que el zumo se clarificó efectivamente. A pesar de que la clarificación por microfiltración a escala de laboratorio no modificara los atributos del sabor, sí se perdieron el color y el aroma característicos del zumo de melocotón. A escala experimental, el proceso de clarificación de membrana afectó a todas las características sensoriales del zumo clarificado, incluido su sabor. El desagradable sabor y aroma de los frutos cocidos podría atenuarse si se clarificara el zumo uniendo los procesos enzimáticos y de membranas. Ni el tipo de la membrana, ni la geometría de membrana ni la presión transmembrana empleados durante la clarificación afectaron sensiblemente las características sensoriales del zumo.

Brasil / Prumus persica / jugo de frutas / calidad / clarificación / microfiltración / ultrafiltración / sabor / color 